\title{
Peertechz
}

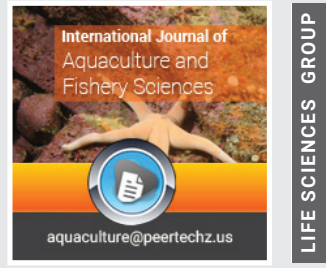

\section{Assessment of Sparus aurata (Gilthead Seabream) stock in Bardawil lagoon, southeast Mediterranean Sea}

\section{Ahmed El-Aiq ${ }^{1}$, Mohamed Raaft ${ }^{1}$, El-Dakar A Youssef ${ }^{1}$, Salem M Ahmed ${ }^{1}$, Ahmed M Al-Beak ${ }^{3 *}$ and Kassem S Ahmed $^{2}$}

${ }^{1}$ Faculty of Aquaculture and Marie Fisheries, Arish University, Egypt

${ }^{2}$ Center Laboratory for Aquaculture Research (CLAR), Egypt

${ }^{3}$ General Authority for Fish Resources Development (GAFRD), Egypt
Received: 13 September, 2021

Accepted: 29 September, 2021

Published: 30 September, 2021

*Corresponding authors: Ahmed M Al-Beak, Faculty of Aquaculture and Marie Fisheries, Arish University, Egypt, Tel: +201007264406, 00201210949634; Email: albeak2020@yahoo.com

ORCID: https://orcid.org/0000-0003-1338-5897

Keywords: Sparus aurata; Stock assessment; Overfishing; Southeast mediterranean sea

Copyright: (c) 2021 El-Aiq A, et al. This is an openaccess article distributed under the terms of the Creative Commons Attribution License, which permits unrestricted use, distribution, and reproduction in any medium, provided the original author and source are credited.

https://www.peertechzpublications.com

\section{Abstract}

During present study period from October 2020 to April 2021, gilthead seabream Sparus aurata stock was estimated by using many assessment models to evaluate actual status on Bardawil lagoon. Length at first capture (LC) was 17.10 and $16.70 \mathrm{~cm}$ for females and males respectively, but it was $16.9 \mathrm{~cm}$ for all individuals that corresponding age at first capture (tc= 2.49 year). Length at first recruit $\mathrm{Lr}$ was 10.70 and $9.70 \mathrm{~cm}$ for females and males, respectively, corresponding age tr= 0.77 year. The length at first maturity was $\mathrm{Lm}=18.18 \mathrm{~cm}$ that corresponding age $\mathrm{tm}=2.85$ years. Virtual population analysis shows some of intensive capture on $S$. aurata at its early life's. Yield per recruit and biomass per recruit tend to collapse as a result of high fishing mortalities. The current study concludes an exact overfishing pressure of S. aurata stock in Bardawil lagoon.

\section{Introduction}

Stock assessment of Sparus aurata throughout Bardawil lagoon did not investigate before. However, it was an important, economical, and most preferred species in this lagoon. Rather than, biological aspects of gilthead seabream were intensively researched by many authors in different geographic locations as by Lasserre and Labourg 1974 [1]; Lasserre, 1976 [2]; Arnal, et al. 1976 [3]; Suau and López 1976 [4]; Chauvet 1979 [5]; Arias 1980 [6]; Ferrari and Chieregato 1981 [7]; Wassef and Eisawy 1985 [8]; Rosecchi, 1987 [9] Seabreams (Sparidae) live in coastal waters world-wide and sustain important recreational and commercial fisheries [10].

Family Sparidae is among the most abundant demersal fishes inhabiting the Egyptian Mediterranean waters, especially in the Bardawil lagoon (Figure 1). Which are caught by trammel net but sometimes by handline.
Gilthead seabream, Sparus aurata (Linnaeus, 1758) is common throughout the Mediterranean and considered as one of the most popular porgies for food. It is a bottom dwelling species and usually lives solitary or in small and loose groups. It is an expensive luxury food so; it is a target for intensive fishing. Recently, it has been widely cultured in many countries including Egypt. In the wild it spawns in the winter months but in aquaculture farms it is conditioned to breed all year round under controlled methods (Moretti, et al. 1999; Lloris 2005). Gilthead seabream observed in many regions as in eastern Atlantic coasts; southern Spanish, southern Portuguese coast and Irish Sea basin, Ireland) [11]. Also, observed through Mediterranean Sea, Bardawil lagoon, Egypt; southwestern Turkish coast [12], Gulf of Lions, Mediterranean, France [13].

It was found in sandy bottoms and sea grass beds as well as in the surf zone commonly to depths of about $30 \mathrm{~m}$, but adults may occur to $150 \mathrm{~m}$ depth. It is a sedentary fish, either solitary or in small aggregations. In spring, they often occur in brackish 


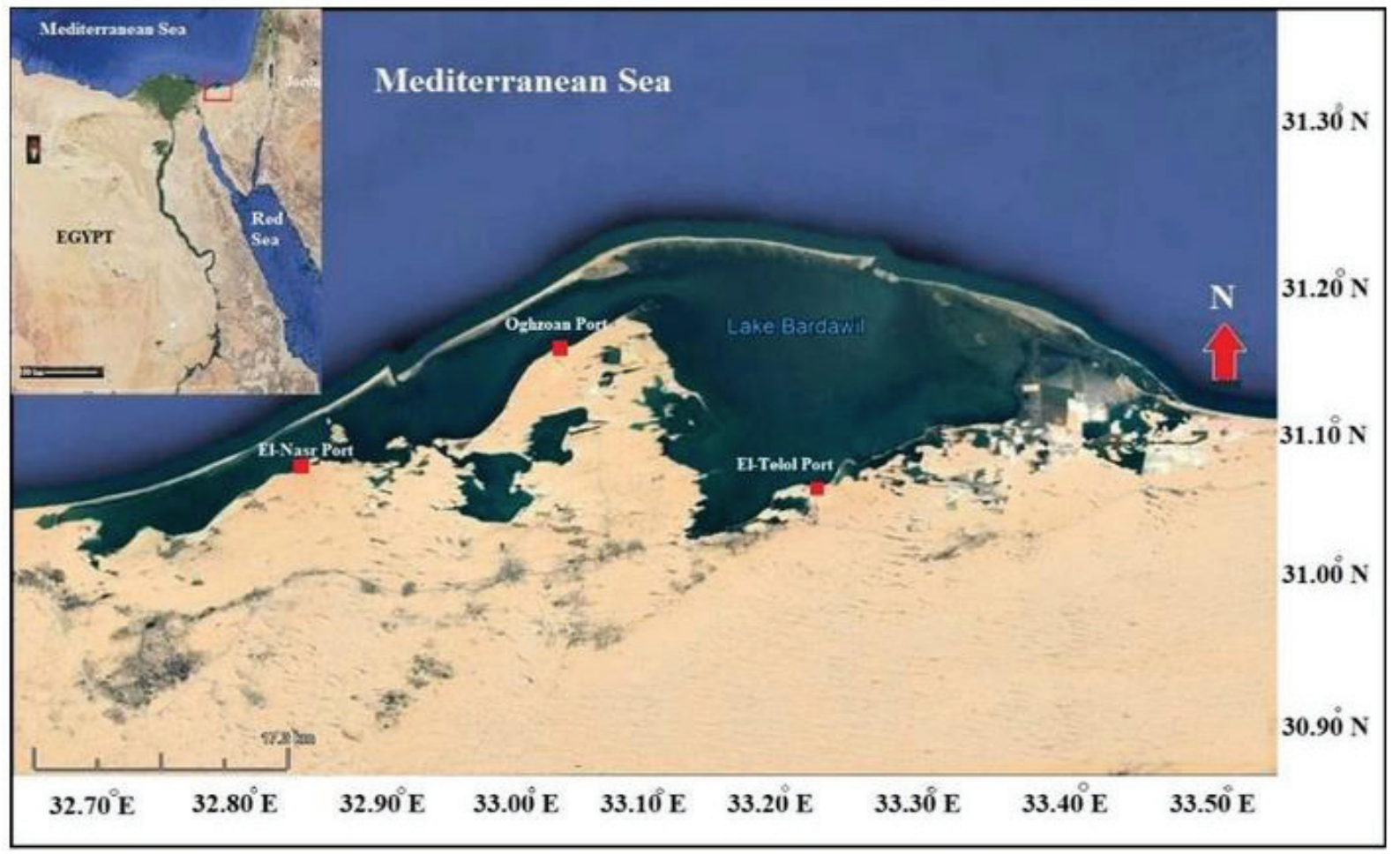

Figure 1: Map of Bardawil lagoon.

water coastal lagoons and estuaries. Gilthead seabream is carnivorous feed on small fishes, shrimps, shellfish, including oysters and mussels. But sometimes it becomes accessorily herbivorous [14].

Gilthead seabream are one of the most favorable marine fishes in Bardawil Lagoon and have a great commercial important in Egypt. It is the main demersal target species of some operating gears as trammel net, hand lines, and long lines.

The main objective of the current investigation is to evaluate Gilthead Seabream fishing rates, recruitment and current yield also to assess its stock in Bardawil lagoon to sustainable management.

\section{Materials and methods}

\section{Study area}

Lake Bardawil is an important hypersaline lake located in Egypt on the coast of the Sinai Peninsula adjacent to the Mediterranean Sea. The lake is host to several industries which provide critical contributions to the regional economy including farmed and wild-caught fisheries and salt extraction. It has been intensively investigated during the last 30 years (Figure 1).

\section{Fish samples}

During seven months from October 2020 to April 2021, a total of 499 specimens of gilthead seabream S. aurata were collected monthly from the landing site at the Bardawil lagoon.

\section{Measurements and data analysis}

The total weight (TW) was measured nearest to $0.01 \mathrm{gm}$ and the total length (TL) nearest to $0.1 \mathrm{~cm}$. Total lengths of $S$. aurata measured was ranged between 9.7 to $26 \mathrm{~cm}$ for males and 10.7 to $29 \mathrm{~cm}$ for females, also, total weights were ranged between 16.6 - 240.3 gm for males and between 22.3 - 325.3 gm for females.

The length at first capture (Lc), was determined from the accumulated catch curve as described in Pauly [15]. Additionally, age at first capture (tc) and age at first recruit was calculated by the equations of Beverton and Holt [16].

This is the average length at first maturity $(\mathrm{Lm})$, which fish of a given population matures for the first time. The value and its standard error are calculated from an empirical relationship between length at first maturity and asymptotic length $\mathrm{L}_{\infty}$ [17].

$\log \mathrm{L} \mathrm{m}=-0.1189+0.9157^{*} \log \mathrm{L}_{\max }$

Where $\mathrm{L}_{\max }$ : are the maximum length reached by fishes.

To analyze the stock status at the current time, Virtual Population Analysis (VPA) with the age-based cohort analysis [18] was used to analyze the historical data for estimation of population parameters.

Yield per recruit (Y/R) and biomass per recruit (B/R) express the yield on a (per recruit basis) and hence the yield is relative to the recruitment, this model can apply in the form suggested by [19] as follows:

$$
\mathrm{Y} / \mathrm{R}=\mathrm{F} \mathrm{e}^{-\mathrm{M}(\mathrm{tc}-\mathrm{tr})} \mathrm{W} \infty[(1 / \mathrm{Z})-(3 \mathrm{~S} / \mathrm{Z}+\mathrm{K})+(3 \mathrm{~S} 2 / \mathrm{Z}+2 \mathrm{~K})-
$$
$(\mathrm{S} 3 / \mathrm{Z}+3 \mathrm{~K})]$ 
Where: Y/R: is the yield per recruit, $S=\mathrm{e}^{-\mathrm{K}(\mathrm{tc}-\mathrm{to})}, \mathrm{W} \infty$ : (live weight in $\mathrm{g}$ ) being the asymptotic weight of the fishes of that stock, $\mathrm{K}$ : is the growth coefficient, F: fishing mortality, Z: is the instantaneous total mortality coefficient, $M$ : is the natural mortality, tc: age at first capture and tr: age at first recruit.

Estimation of the biological reference points (BRP) which consider the long-term yield per recruit $(\mathrm{Y} / \mathrm{R})$, as a function of fishing mortality (F) for a certain exploitation pattern, to calculate $\mathrm{F}_{\max }$ and $\mathrm{F}_{0.1}$ by model that suggested by Cadima, 2003 [20].

\section{Result and Discussion}

\section{Length and age at first capture (Lc and tc)}

The size at $50 \%$ captured of gilthead seabream S. aurata was estimated at $\mathrm{Lc}=17.10$ and $16.70 \mathrm{~cm}$ for females and males respectively where it was $16.9 \mathrm{~cm}$ for all individuals (Figure 2). The smallest length recorded in the catch Lr was 10.70 and 9.70 $\mathrm{cm}$ for females and males, respectively.

Estimation of age at first capture according to this length was done by Beverton and Holt (1956) equation were found $S$. aurata frequently caught in the second $2^{\text {nd }}$ year of life ( $\mathrm{tc}=2.49$ year). On other hand, new recruits were interring the stock firstly in its first year of life as (age at first recruit according to the same length was $\operatorname{tr}=0.77$ year).

In Bardawil lagoon the current value of (Lc) for S. aurata was higher than Ahmed, 2011 and, Al -Zahaby, et al. 2018 $[21,22]$ which found it was 15.54 and $12.85 \mathrm{~cm}$ respectively corresponding age at first capture $\mathrm{tc}=0.6$ and 0.424 years. However, current Lc was less than Mesabh, et al. 2013 [23], which found it was $20 \mathrm{~cm}$. In other region Mehanna, 2007 [24] found that in Port Said fishery, Gilthead seabream captured at size $11.1 \mathrm{~cm}$. The differences between authors regard fishing technique and region of capture.

The size at first recruit of present study was converging with other authors in Bardawil lagoon as (it was found $\mathrm{Lr}=$ 11, 11.9 and $9.59 \mathrm{~cm}$ by Ahmed 2011 [22]; Mesabh, et al. 2013 [23] and Al-Zahaby, et al. 2018 [21] respectively). That means gilthead seabream recruit at small size and be viable for catch at younger age.

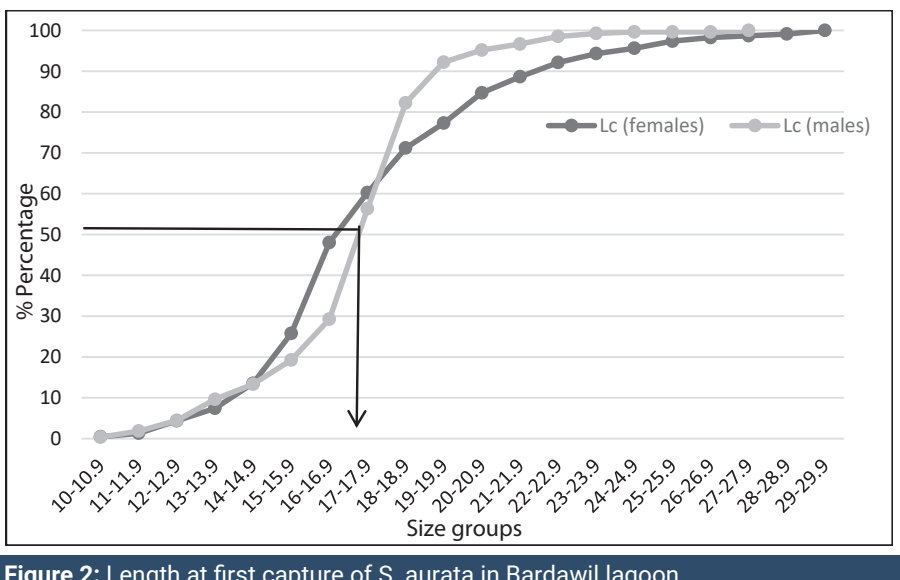

\section{Length and age at first maturity (Lm and tm)}

The length at which $50 \%$ of gilthead seabream $S$. aurata mature (at maturity stage 4 ) was $\mathrm{Lm}=18.18 \mathrm{~cm}$ that corresponding age $\mathrm{tm}=2.85$ years. This result was in agree with Tharwat, et al. 1998 [25]; Ahmed 2011 [22] and Al-Zahaby, et al. 2018 [21] in Bardawil lagoon and agreed with result from Alexandria at southern Mediterranean Sea by Wassef 1978 [26]. But seem to be mature rapidly than fishes were caught from Port Said fishery with $\mathrm{Lm}=25.77 \mathrm{~cm}$ by Mehanna 2007 [24] and in Mellah lagoon, Algeria, were found $\mathrm{Lm}=32.6 \mathrm{~cm}$ by Chaoui, et al. 2006 [27]. The success of reproduction of gilthead seabream could be the result of salinity conditions that are favorable for the osmotic requirements of gametogenesis [28].

\section{Virtual Population Analysis (VPA)}

The cohort model was based on the principle that if we know how many fish died from natural causes and we know how many were caught, we can reconstruct the history of the cohort [29]. At present work, 5 age groups of S. aurata were found in Bardawil lagoon stock. When cohort at age zero that seem, the population have had largest size and the number of individuals was at maximum, then it started to collapse by over the time and age and reaching to its smallest size as in age group $5^{\text {th }}$. Furthermore, the individuals that survive from cohort at one year to the next year were reduced by the increases of natural and fishing mortalities.

Natural mortality (mortality that causes by diseases, predation, and pollution) begins at its highest level in the youngest age groups (age group 0 and 1 ) then decreased to lowest at oldest age groups. At the begging of fish's life, fishing mortality appears to its minimum value $\left(0.419 \mathrm{yr}^{-1}\right)$ at age group zero, before it increases by the increase of age to reach its maximum value at age group $1^{\text {st }}\left(1.169 \mathrm{yr}^{-1}\right)$, then it reduced in oldest age groups (Table 1).

Catches number of S. aurata in Bardawil lagoon seem to be at intensive level at small ages $(43.89 \%$ from total catch was done seriously on age $0,46.15 \%$ from total catch was done seriously on age 1) with high pressure on population size from year to another without chance to self-regeneration.

Cohort analysis or (VPA) was firstly developed as age-based method, which it is generally used for studying and analyzing the dynamics of harvested fish populations. The feature of VPA that is most essential for practical use is that, shown a high fishing pressure, estimates of population size obtained tend to converge rapidly toward their true value, and therefore generally provide and specified a reasonable assessment of natural mortality $(M)$, reliable estimates of recruitment [18]. Present study could be considered as a base for future studies that help to predict the future catch of $S$. aurata in Bardawil lagoon and show that the $S$. aurata died by fishing mortality more than those which die by natural mortality.

\section{Yield and Biomass per recruit (Y/R, B/R)}

The yield per recruit (Y/R) and biomass per recruit (B/R) of $S$. aurata in Bardawil lagoon was found to be $59.28 \mathrm{gm}$ and 105.44

Citation: El-Aiq A, Raaft M, Youssef EA, Ahmed SM, Al-Beak AM, et al. (2021) Assessment of Sparus aurata (Gilthead Seabream) stock in Bardawil lagoon, southeast Mediterranean Sea. Int J Aquac Fish Sci 7(3): 030-034. DOI: https://dx.doi.org/10.17352/2455-8400.000070 
gm respectively at the actual fishing mortality 0.56 year $^{-1}$. By applying different values of fishing mortality coefficient which affecting on yield and biomass per recruit the results show that the maximum value of $(\mathrm{Y} / \mathrm{R})$ and $(\mathrm{B} / \mathrm{R})$ was 60.26 and 150.65 gm with fishing mortality coefficient $\mathrm{F}=0.4$ year $^{-1}$, This means that the present level of fishing mortality coefficient is higher than the fishing mortality coefficient produce the maximum yield per recruit. Biomass per recruit was decreased with the increases of fishing mortality were it was at its maximum (783.07 gm) at $\mathrm{F}=0$ (Table 1$)$.

The present level of fishing mortality showing some pressure on stock biomass of gilthead seabream on Bardawil lagoon, that might cause decline in periodic yield and so stocking collapse and reach dangers level, which need to measure recruitment to a stock over a number of years, an estimate can be obtained not only of the average recruitment but also of the typical variability from year to year.

Mesabh, et al. 2013 [23], found that the maximum yield per recruit increased by the increases of the age at first capture which associated with the increase of mesh size. This means that increases of age at first capture is directly related to the increases of the maximum yield per recruit (Y/R) in spite of the fishing mortality $(\mathrm{F})$.

\section{Biological reference points BRP $\left(F_{\text {max }}, F_{0.1}\right.$ and $\left.F_{p r}\right)$}

Biological Reference Points (BRP) mean the values of $\mathrm{F}$ and $\mathrm{B}$, taking into consideration the best possible catch and/ or ensuring the conservation of the fishery resource. $F_{p r}$ is the present fishing level against $\mathrm{Y} / \mathrm{R}$ also $\mathrm{F}_{01}$ is the value of $\mathrm{F}$, where $\mathrm{Y} / \mathrm{R}$ is equal to 10 percent of $\mathrm{Y} / \mathrm{R}$ maximum, where $\mathrm{F}_{\max }$ can define as the point of the curve of yield per recruit $(\mathrm{Y} / \mathrm{R})$ against fishing mortality $(\mathrm{F})$, where $\mathrm{Y} / \mathrm{R}$ is the maximum (Table 2).

At current study, value of $F_{p r}$ was excessed than $F_{\text {max }}$ and $\mathrm{F}_{0.1}$, which $\mathrm{B}_{\mathrm{pr}}$ was less than $\mathrm{B}_{\max }$ and $\mathrm{B}_{0.1}$ values (Although yield per recruit equal to $98.37 \%$ of its maximum accessible yield from catch, the biomass will decreases to become at $13.47 \%$ from virgin biomass). And the slope of the tangent to the curve is negative for $\mathrm{F}>\mathrm{F}_{\max }$. Maximum fishing level that produces maximum yield was $0.4 \mathrm{yr}^{-1}$ also target fishing level $\mathrm{F}_{0.1}$ was 0.18 $\mathrm{yr}^{-1}$ (which yield per recruit equal to $90.25 \%$ of its maximum accessible yield from catch, and biomass will present $35.58 \%$ from virgin biomass). Consequently, the current fishing level was $0.56 \mathrm{yr}^{-1}$ causing growth overfishing with dramatically decline in total fish biomass in the lagoon Figure 3

Table 1: Virtual population analysis of $S$. aurata by age groups

\begin{tabular}{|c|c|c|c|c|c|}
\hline Age groups & $\begin{array}{c}\text { Population } \\
\text { no. }\end{array}$ & Survivors & $\begin{array}{c}\text { Natural } \\
\text { death }\end{array}$ & Catches no. & $\begin{array}{c}\text { Fishing } \\
\text { mortality }\end{array}$ \\
\hline O & 6776851 & 3536260 & 1176377 & 2064214 & 0.419 \\
\hline I & 3536260 & 871477 & 494165 & 2170617 & 1.169 \\
\hline II & 871477 & 501632 & 157040 & 212806 & 0.320 \\
\hline III & 501632 & 303074 & 92155 & 106403 & 0.272 \\
\hline IV & 303074 & 164555 & 53397 & 85122 & 0.379 \\
\hline V & 164555 & 0 & 100713 & 63842 & 0.562 \\
\hline
\end{tabular}

Table 2: Yield and biomass per recruit as a function of fishing mortality.

\begin{tabular}{|c|c|c|}
\hline Fishing Mortality & Yield per recruit (gm) & Biomass per recruit (gm) \\
\hline 0.00 & 0.000 & 783.07 \\
\hline 0.10 & 43.24 & 432.41 \\
\hline 0.12 & 47.08 & 392.31 \\
\hline 0.14 & 50.10 & 357.87 \\
\hline 0.16 & 52.49 & 328.08 \\
\hline 0.18 & 54.38 & 302.12 \\
\hline 0.20 & 55.87 & 279.36 \\
\hline 0.22 & 57.04 & 259.28 \\
\hline 0.24 & 57.96 & 241.48 \\
\hline 0.26 & 58.66 & 225.62 \\
\hline 0.28 & 59.20 & 211.42 \\
\hline 0.30 & 59.60 & 198.65 \\
\hline 0.35 & 60.15 & 171.84 \\
\hline 0.40 & 60.26 & 150.65 \\
\hline 0.45 & 60.11 & 133.57 \\
\hline 0.50 & 59.79 & 119.59 \\
\hline 0.56 & 59.28 & 105.44 \\
\hline 0.60 & 58.92 & 98.21 \\
\hline 0.65 & 58.44 & 89.90 \\
\hline 0.70 & 57.94 & 82.77 \\
\hline 0.75 & 57.45 & 76.60 \\
\hline 0.80 & 56.97 & 71.21 \\
\hline 0.85 & 56.50 & 66.47 \\
\hline 0.90 & 56.05 & 62.28 \\
\hline 0.95 & 55.62 & 58.55 \\
\hline 1.00 & 55.21 & 55.21 \\
\hline 1.25 & 53.42 & 42.73 \\
\hline 1.50 & 52.01 & 34.68 \\
\hline
\end{tabular}

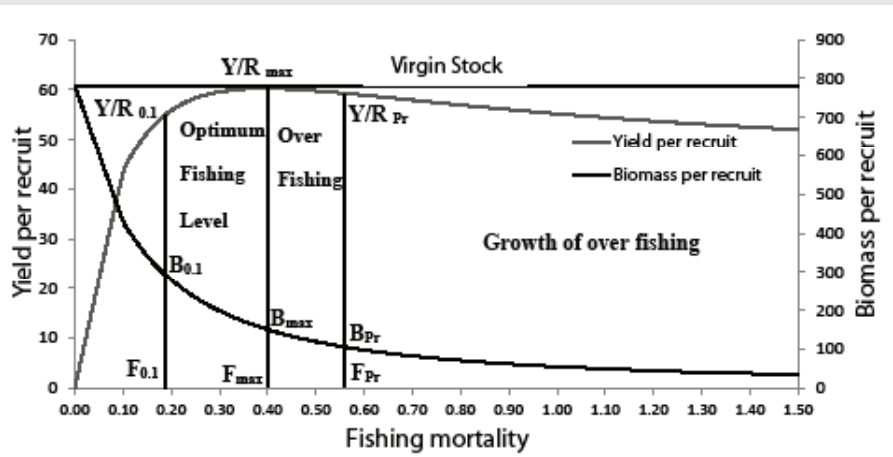

Figure 3: Biological reference points, $\mathrm{F}_{0,1}, \mathrm{~F}_{\mathrm{max}}$ and $\mathrm{F}_{\mathrm{P}^{\prime}}$ of Sparus aurata in Bardawil lagoon.

\section{Conclusion}

Current research show an overfishing pressure on Sparus aurata stock in Bardawil lagoon that made by two causes firstly, by high vessels effort on the lagoon; secondly by fishing small fishes that not access to its first maturity to produce a new generation.

Citation: El-Aiq A, Raaft M, Youssef EA, Ahmed SM, Al-Beak AM, et al. (2021) Assessment of Sparus aurata (Gilthead Seabream) stock in Bardawil lagoon, southeast Mediterranean Sea. Int J Aquac Fish Sci 7(3): 030-034. DOI: https://dx.doi.org/10.17352/2455-8400.000070 


\section{References}

1. Lasserre G, Labourg PJ (1974) Etude comparée de la croissance de la daurade Sparus aurata L. des régions d'Arcachon et de ète. Vie Milieu 24: 155-170. Link: https://bit.ly/3uv62wv

2. Lasserre G (1976) Dynamique des populations ichthyologiques lagunaires. Application à Sparus aurata. Ph. D. thesis, Univ. Montpellier II.

3. Arnal J AG, Alcazar, Ortega A (1976) Observaciones sobre el crecimento de la dorada (Sparus aurata L.) en el Mar Menor (Murcia). Bol. Inst. Esp. Oceanogr 221-222: 1-17.

4. Suau P, López J (1976) Contribución al estudio de la dorada, Sparus aurata L. Inv Pesq 40: 169-199.

5. Chauvet C (1979) Préliminaire à l'étude de la biologie et de la dynamique du stock tunisien de Sparus aurata (L. 1758). Synopsis de la croissance groupes 0, 1, 2. Bull Off Nat Pêches 3: 241-253.

6. Arias A (1980) Crecimento, régimen, alimentarión y reproducción de la dorada (Sparus aurata L.) y del róbalo (Dicentrarchus labrax L.) en los esteros de Cádiz. Inv Pesq 44: 59-83.

7. Ferrari I, Chieregato AR (1981) Feeding habits of juvenile stages of Sparus aurata L., Dicentrarchus labrax L. and Mugilidae in a brackish embayment of the Po River delta. Aquaculture 25: 243-257. Link: https://bit.ly/3mcd70F

8. Wassef EA, Eisawy A (1985) Food and feeding habits of wild and reared gilthead bream Sparus aurata L. Cybium 9: 233-242. Link: https://bit.ly/3kXMT2Z

9. Rosecchi E (1987) L'alimentation de Diplodus annularis, Diplodus sargus, Diplodus vulgaris et Sparus aurata (Pisces, Sparidae) dans le Golfe du Lion et les lagunes littorals. Rev Trav Inst Pêches Marit 49: 125-141.

10. Fischer W, Schneider M, Bauchot ML (1987) Fiches FAO d'identification des espèces pour les besoins de la pêche. (Rev. 1). Méditerranée et mer Noire. Zone de pêche 37 . Vol. I. Végétaux et Invertébrés (FAO species identification cards for needs of fishing (Rev. 1). Mediterranean and Black Sea. Fishing area 37. Vol. I Plants and Invertebrates). Rome, FAO 1: 1-760. Link: https://bit.ly/3kVcKsv

11. Craig G, Paynter D, Coscia I, Mariani S (2008) Settlement of gilthead sea bream Sparus aurata L. in a southern Irish Sea coastal habitat. Journal of Fish Biology 72: 287-291. Link: https://bit.ly/2Wu12LX

12. Balik I, Emre Y (2013) Monthly variation in stock density and growth performance of juvenile gilthead seabream (Sparus aurata L., 1758) in Beymelek Lagoon, Antalya, Turkey. Pakistan J Zool 45: 687-693. Link: https://bit.ly/3CWhJiA

13. Lény M, Panfili J, Paillon C, N'diaye A, Mouillot D, et al. (2011) Otolith reading and multi-model inference for improved estimation of age and growth in the gilthead seabream Sparus aurata (L.). Estuarine Coastal and Shelf Science 92 534-545. Link: https://bit.ly/3B31q35

14. Bauchot ML, Hureau JC (1990) Sparidae. p. 790-812. In JC Quero, JC Hureau C Karrer, A Post and L Saldanha (eds.) Check-list of the fishes of the eastern tropical Atlantic (CLOFETA). JNICT, Lisbon; SEI, Paris; and UNESCO, Paris. 2.

15. Pauly D (1984) Fish population dynamics in tropical water: a manual for use with programmable calculators. ICLARM Stud Rev 8: 325. Link: https://bit.ly/2Y7ggYh

16. Beverton RJH, Holt SJH (1956) A review of methods for estimating mortality rates in exploited fish populations, with special reference to sources of bias in catch sampling. Rapp P Réun CIEM 140: 67-83. Link: https://bit.ly/314mpgB

17. Froese R, Binohlan C (2000) Empirical relationships to estimate asymptotic length, length at first maturity and length at maximum yield per recruit in fishes, with a simple method to evaluate length frequency data. J Fish Biol 56 : 758-773. Link: https://bit.ly/3mkKb7s
18. Pope JG (1972) An investigation of accuracy of virtual population analysis using cohort analysis. Res Bull ICNAF 65-74. Link: https://bit.ly/3md7qil

19. Gulland JA (1969) Manual of methods for fish stock assessment. Part (1). Fish population analysis. FAO Man Fish Sci 4: 154. Link: https://bit.ly/3zZCdp1

20. Cadima LE (2003) Fish stock assessment manual. FAO Fisheries Technical Paper. no. 303. Rome, FAO 161. Link: https://bit.ly/2YhsPAf

21. Al-Zahaby AS, El-drawany MA, Mahmoud HH, Abdalla MAF (2018) Some biological aspects and population dynamics of the Gilthead Sea bream from Bardawil lagoon, Sinai, Egypt. Egypt J Aqu Biol Fish 22: 295- 308. Link: https://bit.ly/39UYv04

22. Ahmed MS (2011) Population dynamics and fisheries management of Gilthead seabream, Sparus aurata (f. Sparidae) from Bardawil lagoon, North Sinai, Egypt, Egypt. J Aqu Biol Fish 15: 57- 69. Link: https://bit.ly/3D5fSli

23. Mesabh M, Hassanen GDI, Hussein MS, EL Aiatt AAO, Mohammed G (2013) Growth, Mortality and Yield per Recruit of Gilthead sea Bream, Sparus aurata in Bardawil Lagoon, North Sinai, Egypt. SINAI Journal of Applied Sciences 2 75-86. Link: https://bit.ly/3F7iXK4

24. Mehanna SF (2007) A Preliminary Assessment and Management of Gilthead Bream Sparus aurata in the Port Said Fishery, the Southeastern Mediterranean Egypt. Turkish Journal of Fisheries and Aquatic Sciences 7: 123-130. Link: https://bit.ly/3opwre6

25. Tharwat AA, Emam WM, Ameran MA (1998) Stock assessment of the Gilthead sea bream Sparus aurata from Bardawil lagoon, North Sinai, Egypt. J Aquat Biol Fish 2: 483-504

26. Wassef E (1978) Biological and physiological studies on marine and acclimatized fish Chrysophrys auratus. PhD. thesis. Cairo: Fac. Sci. Cairo Univ.

27. Chaoui L, Kara MH, Faure E, Quignard JP (2006) Growth and reproduction of the gilthead seabream Sparus aurata in Mellah lagoon (north-eastern Algeria). Scientia Marina 70: 545-552. Link: https://bit.ly/3ilD900

28. Draredja B, Kara MH (2004) Caractères physico-chimiquesde la lagune Mellah (Algérie Nord-Est). Rapp. Comm Int MerMédit 37: 93.

29. Al-Beak AM (2016) Fisheries management of round sardinella Sardinella aurita along North Sinai coast. J Coast Life Med 4: 505-509. Link: https://bit.ly/3uruRJP

\section{Peertechz Publications}

Highlights

* Signatory publisher of ORCID

* Signatory Publisher of DORA (San Francisco Declaration on Research Assessment)

* Articles archived in worlds' renowned service providers such as Portico, CNKI, AGRIS, TDNet, Base (Bielefeld University Library), CrossRef, Scilit, J-Gate etc.

* Journals indexed in ICMJE, SHERPA/ROMEO, Google Scholar etc.

* OAI-PMH (Open Archives Initiative Protocol for Metadata Harvesting)

* Dedicated Editorial Board for every journa

* Accurate and rapid peer-review process

* Increased citations of published articles through promotions

* Reduced timeline for article publication

Submit your articles and experience a new surge in publication services (https://www.peertechz.com/submission).

Citation: El-Aiq A, Raaft M, Youssef EA, Ahmed SM, Al-Beak AM, et al. (2021) Assessment of Sparus aurata (Gilthead Seabream) stock in Bardawil lagoon, southeast Mediterranean Sea. Int J Aquac Fish Sci 7(3): 030-034. DOI: https://dx.doi.org/10.17352/2455-8400.000070 